\title{
Comment on "Ebola Virus Infection among Western Healthcare Workers Unable to Recall the Transmission Route"
}

\author{
Mark G. Kortepeter, ${ }^{1,2,3}$ Theodore J. Cieslak, ${ }^{4}$ Elena H. Kwon, ${ }^{5}$ Philip W. Smith, ${ }^{6}$ \\ Christopher J. Kratochvil, ${ }^{7,9,9}$ and Angela L. Hewlett ${ }^{10}$ \\ ${ }^{1}$ Medical Division, Laulima Government Solutions, Orlando, FL, USA \\ ${ }^{2}$ US Army Medical Research Institute of Infectious Diseases (USAMRIID), Fort Detrick, MD, USA \\ ${ }^{3}$ College of Public Health, University of Nebraska, Omaha, NE, USA \\ ${ }^{4}$ Nebraska Biocontainment Unit and College of Public Health, University of Nebraska, Omaha, NE, USA \\ ${ }^{5}$ Medical Division, USAMRIID, 1425 Porter Street, Fort Detrick, MD 21702, USA \\ ${ }^{6}$ College of Public Health, University of Nebraska Medical Center, Omaha, NE, USA \\ ${ }^{7}$ University of Nebraska Medical Center, Omaha, NE, USA \\ ${ }^{8}$ Nebraska Medicine, Omaha, NE, USA \\ ${ }^{9}$ UNeHealth, Omaha, NE, USA \\ ${ }^{10}$ Division of Infectious Diseases and Nebraska Biocontainment Unit, University of Nebraska Medical Center, Omaha, NE, USA \\ Correspondence should be addressed to Mark G. Kortepeter; mark.kortepeter@gmail.com
}

Received 14 February 2017; Accepted 3 August 2017; Published 20 September 2017

Academic Editor: Gelin Xu

Copyright ( 2017 Mark G. Kortepeter et al. This is an open access article distributed under the Creative Commons Attribution License, which permits unrestricted use, distribution, and reproduction in any medium, provided the original work is properly cited.

We read with interest the recent paper by Petti et al. entitled "Ebola Virus Infection among Western Healthcare Workers Unable to Recall the Transmission Route" [1]. Although the article relies on prior reports from healthcare organizations or magazine and newspaper articles rather than direct interviews with the patients themselves, we still believe the article potentially validates some of our concerns related to caring for patients infected with Ebola virus.

During the 2014-16 Ebola virus outbreak in West Africa, healthcare workers were at greater risk of infection than the population at large [2]. The African healthcare environment is much less controlled than a developed-world healthcare facility; however, as noted by Petti et al. [1], in both developed and underdeveloped settings, even contacts deemed to be low risk ended up becoming infected. Without an easily identifiable breach in personal protective measures, such as a recognized mucosal splash or needle stick, it is impossible to pinpoint definitively the exact moment or mechanism of exposure.
We still have much to learn regarding potential exposure mechanisms and exposure routes in the clinical setting. Therefore, as we have argued previously, there is no room for error with a disease like Ebola that leads to the production of copious amounts of body fluids with high viral titers, along with the usual challenges of following infection control and safety protocols to the letter in any healthcare setting [3]. This is why we continue to advocate for the utilization of high-level containment care units, when such facilities are available, for viral hemorrhagic fevers that have demonstrated infection of healthcare workers, like Ebola, Marburg, Crimean Congo hemorrhagic fever, and Lassa viruses, and potentially others [4]. This option protects caregivers through sophisticated engineering controls (directional airflow, hot/cold designations to identify graduated infection risk, and pass-through autoclaves), restricted access, staff who are well-practiced in donning and doffing protocols, and other unique infection control practices needed to limit spread to healthcare workers [5]. 


\section{Disclosure}

The views expressed herein are those of the authors and do not reflect the official policy or position of the US Army Medical Research Institute of Infectious Diseases, the Medical Research and Materiel Command, the US Army Medical Department, the Department of the Army, Department of Defense, or the US Government. The views expressed also do not reflect those of the School of Public Health or University of Nebraska Medical Center.

\section{Conflicts of Interest}

The authors declare that they have no conflicts of interest.

\section{References}

[1] S. Petti, C. Protano, G. A. Messano, and C. Scully, "Ebola virus infection among western healthcare workers unable to recall the transmission route," BioMed Research International, vol. 2016, Article ID 8054709, 2016.

[2] World Health Organization, "Health worker infections in Guinea, Liberia, and Sierra Leone: a preliminary report," 2015, http://www.who.int/csr/resources/publications/ebola/healthworker-infections/en/.

[3] M. G. Kortepeter, P. W. Smith, A. Hewlett, and T. J. Cieslak, "Caring for patients with Ebola: a challenge in any care facility," Annals of Internal Medicine, vol. 162, no. 1, pp. 68-69, 2015.

[4] M. G. Kortepeter, E. H. Kwon, A. L. Hewlett, P. W. Smith, and T. J. Cieslak, "Containment care units for managing patients with highly hazardous infectious diseases: a concept whose time has come," Journal of Infectious Diseases, vol. 214, pp. S137-S141, 2016.

[5] A. L. Hewlett, J. B. Varkey, P. W. Smith, and B. S. Ribner, "Ebola virus disease: preparedness and infection control lessons learned from two biocontainment units," Current Opinion in Infectious Diseases, vol. 28, no. 4, pp. 343-348, 2015. 


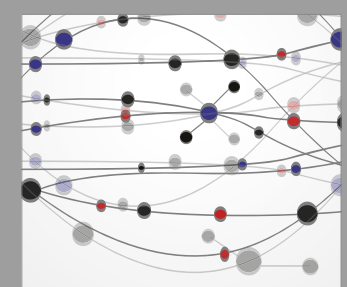

The Scientific World Journal
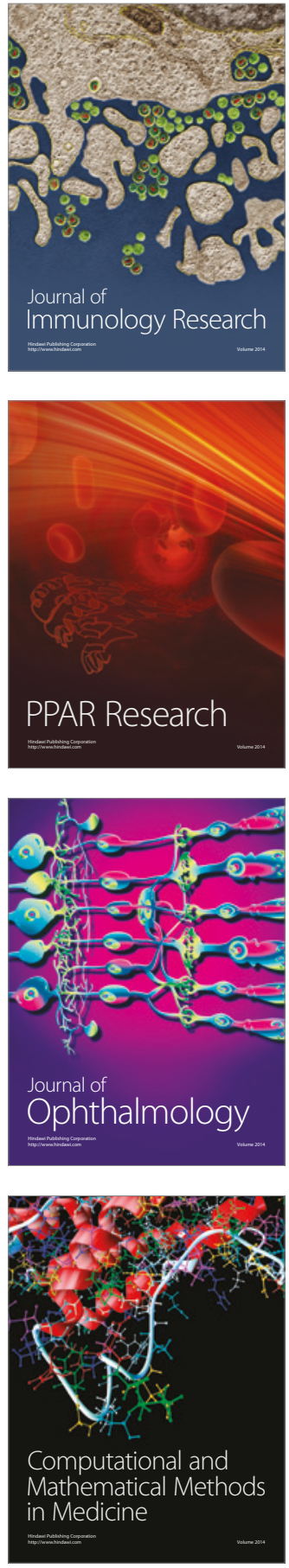

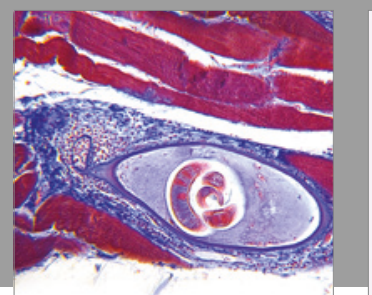

Gastroenterology Research and Practice
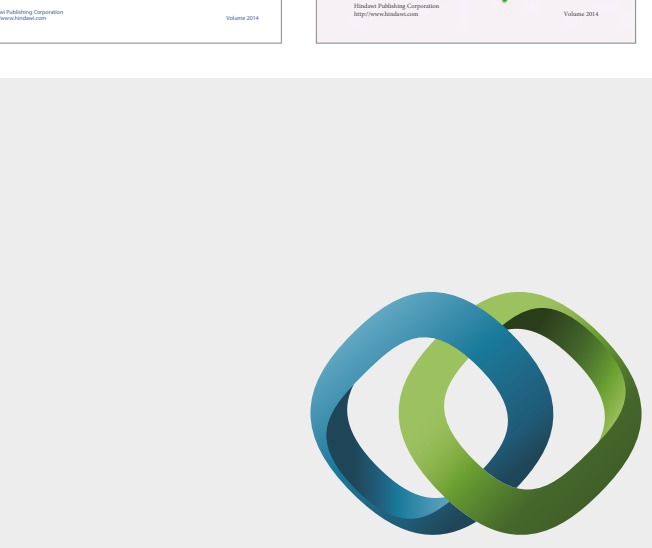

\section{Hindawi}

Submit your manuscripts at

https://www.hindawi.com
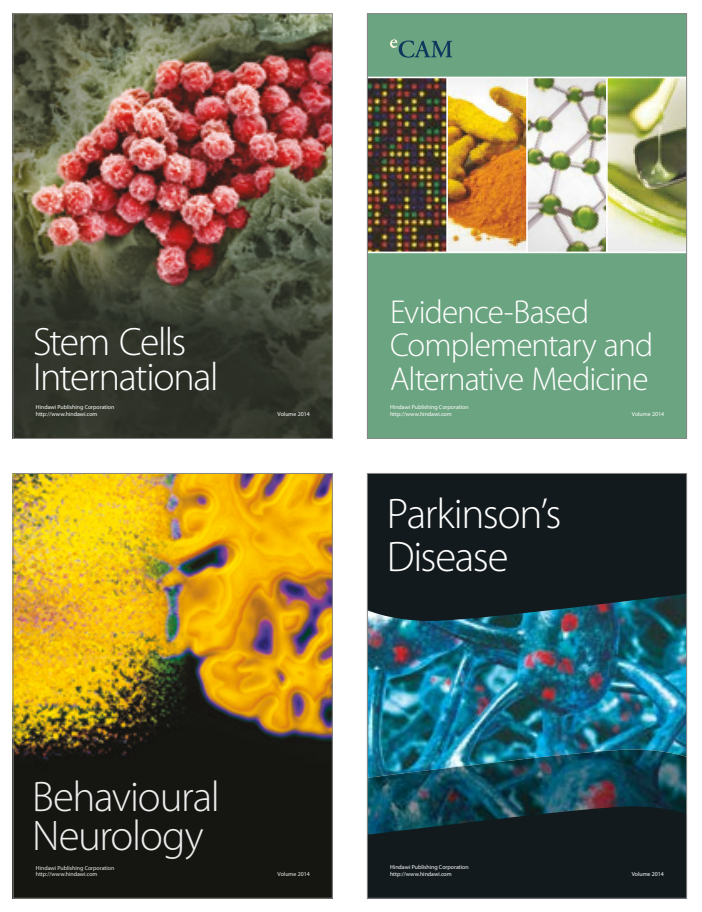
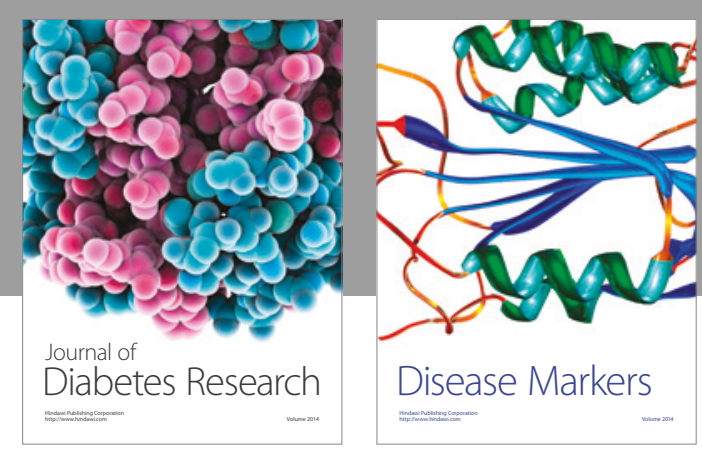

Disease Markers
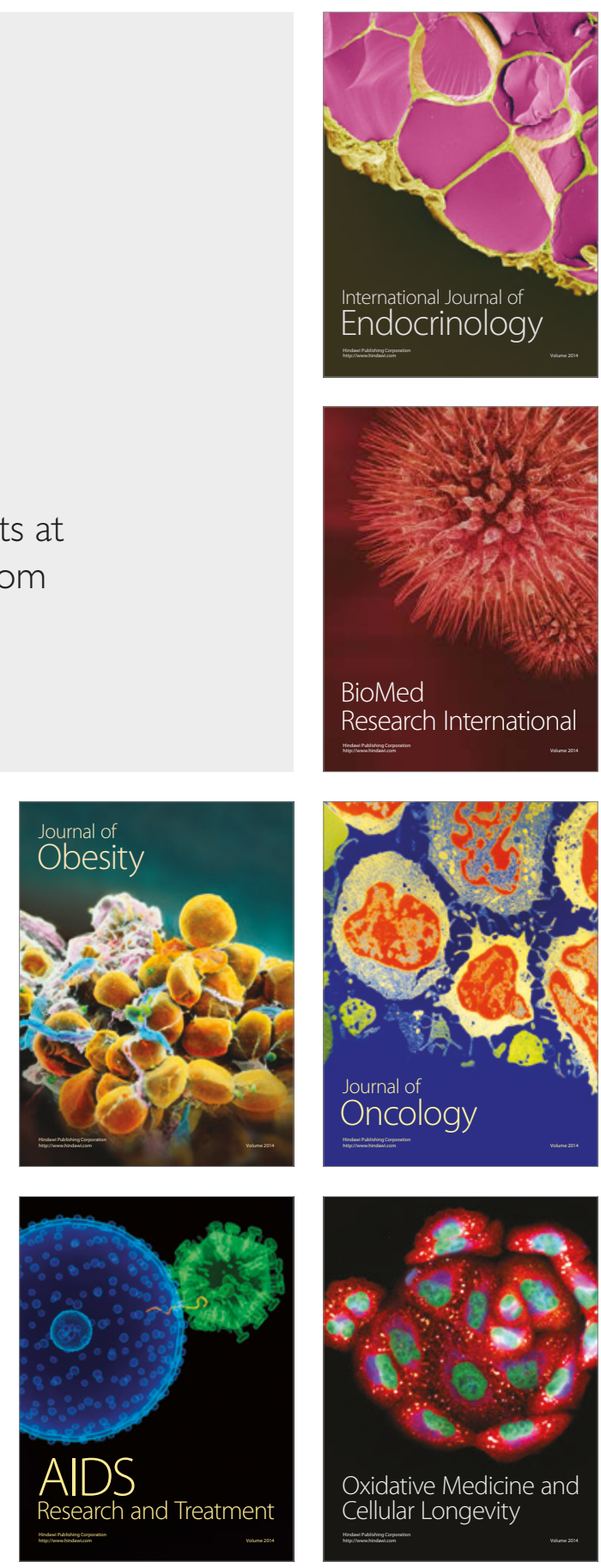